\title{
Csővel körülölelt, fémhabalapú kompozitok gyártása, hőkezelése és vizsgálata
}

\section{Manufacturing, Heat Treatment and Investigation of Foam-Filled Tubes}

\author{
Kincses Domonkos Balázs,, ${ }^{1,2, a}$ Kemény Alexandra,,2,b Leveles Borbála,,,2,c \\ Károly Dóra ${ }^{1,2, d}$ \\ ${ }^{1}$ Budapesti Müszaki és Gazdaságtudományi Egyetem, Gépészmérnöki Kar, Anyagtudomány és Technoló- \\ gia Tanszék, Budapest, Magyarország \\ ${ }^{2}$ MTA-BME Lendület Kompozit Fémhabok Kutatócsoport, Budapest, Magyarország \\ a kincsesd@edu.bme.hu, ${ }^{b}$ alexa@eik.bme.hu, ${ }^{c}$ borbala.leveles@edu.bme.hu, ${ }^{d}$ kdora@eik.bme.hu
}

\begin{abstract}
Composite metal foams are hybrid structures with the main advantages of high specific strength and mechanical energy absorption associated with low density. In the course of our research, we successfully manufactured functional metal foams of EN AC-44200 matrix filled with lightweight expanded clay aggregate particles (LECAPs) in EN AW-6060 alloy tubes with a diameter of $50 \mathrm{~mm}$ and a wall thickness of $5 \mathrm{~mm}$. Manufacturing was performed by low-pressure infiltration directly into the aluminium tube. Six different types of samples were examined: metal matrix syntactic foam, in-situ metal foam, ex-situ metal foam, and their heat-treated pairs. In the compression tests, the heat treatment provided a visible improvement in the results of the ex-situ metal foams.
\end{abstract}

Keywords: functional metal foam, microstructural analysis, LECAP, heat treatment.

\section{Összefoglalás}

A fémhabalapú kompozitok olyan hibrid szerkezetek, amelyek legfontosabb előnyei a kis sűrüség mellé társuló nagy fajlagos szilárdság és a mechanikaienergia-elnyelő képesség. Kutatásunk során EN AW-6060 anyagú, $50 \mathrm{~mm}$ átmérőjü és $5 \mathrm{~mm}$ falvastagságú csőbe helyezett, duzzasztott agyagkavics cellaképző ágyazatot infiltráltunk EN AC-44200 olvadékkal, így állítva elő szintaktikusfémhab-alapú kompozitot. A fémhabalapú kompozit gyártását kisnyomású infiltrálással végeztük az alumíniumcső nyomás alá helyezésével. Hat különböző mintát vizsgáltunk: szintaktikus fémhabot, csőben infiltrált, illetve utólag csőbe sajtolt, előtte adott méretüre esztergált szintaktikus fémhab tömböt, valamint ezek hőkezelésen átesett párját. A zömítővizsgálatok eredményei alapján a hőkezelés jól látható javulást hozott a fémhabalapú kompozitok nyomó igénybevétellel szembeni ellenállásában.

Kulcsszavak: fémhabalapú kompozitok, mikroszerkezeti vizsgálatok, duzzasztott agyagkavics, hőkezelés.

\section{Bevezetés}

Szerkezeti anyagként a fémhabalapú kompozitok gyárthatósága, szilárdsága és tönkremeneteli folyamatának ismerete különösen fontos a tervezhetőség biztosítása érdekében [1-3]. Kutatási munkánk fő céljai különböző, szintaktikus fém- habbal kitöltött csövek gyártása és fejlesztése, valamint a mechanikai tulajdonságok feltérképezése kvázistatikus zömítővizsgálatokkal. A fentiek teljesítéséhez és megértéséhez mikroszerkezeti és mechanikai anyagvizsgálatokat végeztünk.

A szintaktikus fémhabokat általában önmagukban állítják elő, nem funkcionális szerkezeti 
elemekként. A közelmúltban folytak kutatások a fémhabokkal kitöltött csövekről, amelyek többnyire vékony falú csövekbe sajtolt alumíniummátrixú, fémhabalapú kompozitokat tárgyalnak [4-8], de akadnak olyanok is, ahol vékony falú alumíniumcsövet tartalmazó fémhabalapú kompozitokat gyártottak [9], valamint porkohászati úton, habosítási technikával csőben előállított fémhabalapú kompozitokról szóló cikkek is megtalálhatók [10].

\section{Anyagok és módszerek}

\subsection{Felhasznált anyagok}

Kutatásunk során EN AC-44200 mátrixú szintaktikus fémhabokkal töltöttünk ki EN AW-6060 ötvözetű csöveket. Töltőanyagként a Liapor $\mathrm{GmbH}$ \& Co. KG által forgalmazott duzzasztott agyagkavics- (LECA-) részecskéket alkalmaztunk, amely kémiai összetétele szerint főként $\mathrm{SiO}_{2}$-, $\mathrm{Al}_{2} \mathrm{O}_{3}$ - és $\mathrm{Fe}_{2} \mathrm{O}_{3}$-oxidokat tartalmaz. A részecskék belső szerkezete adja az előállított fémhab porozitását.

\subsection{Vizsgálati próbatestek gyártása}

A vizsgálatokhoz 6 különböző típusú mintát készítettünk elő: egy lépésben, közvetlenül a csőbe infiltrálással előállított (továbbiakban in-situ) és csőbe sajtolt (továbbiakban ex-situ) fémhabalapú kompozitokat, fémhabokat önmagukban, valamint ezek hőkezelésen átesett párjait (1. táblázat).

Az in-situ fémhabalapú kompozitokat kisnyomású infiltrálással állítottuk elő, ahol az olvadt mátrixanyagot közvetlenül öntöttük a LECA-részecskékkel töltött EN AW-6060 csőbe. Az infiltrációs paramétereket gondosan be kell állítani, mivel az olvadék átolvaszthatja a más összetételü alumíniumcső falát.

Az öntéshez először a töltőanyag-részecskéket készítettük elő: Ø3,5-4 mm átlagos átmérőjű LECArészecskéket helyeztünk véletlen szoros elrendezésben az előzetesen az alján lehegesztett $\emptyset 50 \mathrm{~mm}$ külső és $\emptyset 40 \mathrm{~mm}$ belső átmérőjű alumíniumötvözet (EN AW-6060) csövekbe. A cső lezárt aljára furatot helyeztünk a gázkivezetés érdekében, és egy rozsdamentes acélhálóval leszorított $\mathrm{Al}_{2} \mathrm{O}_{3}$ paplannal tömtük ki, hogy megakadályozzuk az olvadék átfolyását. A részecskék tetejére szintén

1. táblázat. Vizsgált próbatesttípusok darabszáma

\begin{tabular}{|l|c|c|c|}
\hline & In-situ & Ex-situ & Fémhab \\
\hline Nem hőkezelt (O) & 3 & 2 & 3 \\
\hline Hőkezelt (T6) & 3 & 2 & $1^{*}$ \\
\hline
\end{tabular}

*Az EN AC-44200 ötvözet nem kiválásosan keményíthető rozsdamentes acélhálót helyeztünk, azok elmozdulásának és az olvadékban történő felúszásának megakadályozása érdekében.

A részecskékkel megtöltött csöveket kemencében 45 percig $530^{\circ} \mathrm{C}$-on előhevítettük. Az EN AC-44200 ötvözetet indukciós olvasztókemencében hevítettük izzó állapotig. Miután elérte a kis viszkozitású olvadékállapotot, az olvasztókemencét kikapcsoltuk, és hűlés közben az olvadék hőmérsékletét digitális hőmérővel ellenőriztük. Az EN AW-6060 ötvözet olvadáspontja valamivel nagyobb $\left(650^{\circ} \mathrm{C}\right)$, mint az EN AC-44200 ötvözeté $\left(585^{\circ} \mathrm{C}\right)$, ezért az olvadék a csőbe helyezett részecskék közé infiltrálható anélkül, hogy a csőfalon átolvadna. Amikor az olvadék hőmérséklete elérte a $650^{\circ} \mathrm{C}$-ot, elkezdtük a csőbe önteni, és egy szigetelt pipán keresztül ráadtuk az infiltráláshoz szükséges gáznyomást ( $350 \mathrm{kPa}$, argon). Lehűlés után a mintákat 40 mm-es magasságú darabokra vágtuk a zömítővizsgálatokhoz, amely minták sürüségét is megmértük.

A szintaktikus fémhabokat hasonlóan gyártottuk, mint a habbal kitöltött csöveket, de alumíniumcső helyett egy acél zártszelvényt használtunk, és a mintákat kimunkáltuk $\emptyset 40 \times 40 \mathrm{~mm}$ méretű hengerekre. A csőbe sajtolt fémhabtömb mint kompozit előállításához szintén a kimunkált szintaktikusfémhab-darabokat helyeztük az üres csövekbe szoros illesztéssel (1. ábra).

Az alumíniumötvözetek szilárdságának növelése érdekében hőkezelést végeztünk a minták egy részén, mivel a cső alapanyaga EN AW-6060, amely kiválásosan keményíthető ötvözet.

A hőkezelés során első lépésben oldatba viszszük az ötvözőt, majd a kiválást vízben történő gyorshűtéssel megakadályozzuk. Az öregítés során a vegyület fázis a túltelített szilárd oldatból nagyon diszperz formában válik ki, és hatékonyan növeli a szilárdságot. A hőkezelés lépéseit a következőkben határoztuk meg: hevítés $300{ }^{\circ} \mathrm{C}$ /óra sebességgel, majd hőn tartás $500{ }^{\circ} \mathrm{C}$-on 2 órán át. Ezt követően gyorshütés vízben. Utá-

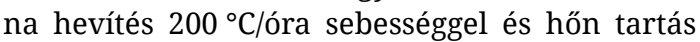
$200{ }^{\circ} \mathrm{C}$-on 3 órán át. Végül gyorshütés vízben.

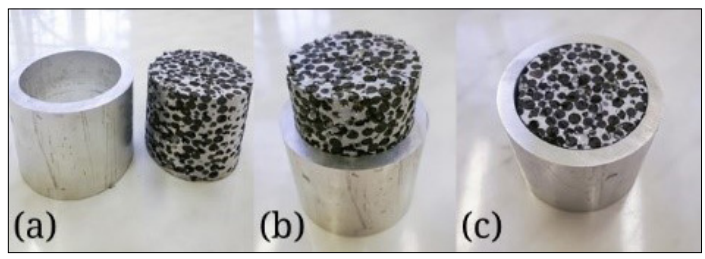

1. ábra. (a) Kimunkált fémhabtömb és üres cső, $(b, c)$ fémhabtömb csőbe sajtolása 


\subsection{Mérési módszerek}

A gyártott fémhabalapú kompozitok mikroszerkezeti vizsgálatára pásztázó elektronmikroszkópos (SEM) felvételeket készítettünk az előzetesen polírozott felületű mintákról.

Az 1. táblázatban jelölt mintákon vizsgálatokat végeztünk az ISO 13314:2011 szabvány alkalmazásával a mechanikai tulajdonságok értékelésére. A kvázi-statikus zömítővizsgálatokat Instron 5989 univerzális, elektromechanikus anyagvizsgáló gépen végeztük $600 \mathrm{kN}$ méréshatárú erőmérő cellával, illetve Zwick/Roell Z400RED univerzális anyagvizsgáló gépen 400 kN méréshatárú erőmérő cellával $4 \mathrm{~mm} / \mathrm{min}$ keresztfejsebességgel. A súrlódás csökkentése érdekében $0,3 \mathrm{~mm}$ vastag, Kolofol márkájú teflonfóliát helyeztünk fel a próbatestek tetejére és aljára a szerszámlappal való érintkezésnél. Az összehasonlíthatóság érdekében minden próbatestet legalább 50\% mérnöki alakváltozásig zömítettünk, és meghatároztuk a maximális nyomófeszültség $\left(\sigma_{c}\right)$ és elnyelt energia- (W50\% a görbe alatti terület) értékeket $50 \%$ mérnöki alakváltozásig.

\section{Eredmények}

A SEM-képeken különböző méretű és eloszlású kiválások (fehér részek) vannak jelen mindkét anyagban. Megfigyelhető, hogy az ötvözetek (a cső és a mátrixanyag) között nincs hézag. A hőkezelt mintában a kiválások mindkét ötvözetben kisebb méretűek és sűrübb eloszlásúak (2. ábra).

A nem hőkezelt próbatestek görbéit összehasonlítva a hőkezelt próbatestek görbéivel (3. ábra) látható, hogy a hőkezelés jelentős hatással volt az ex-situ fémhabalapú kompozitok tulajdonságaira. A görbecsoportok megközelítőleg 20\% alakválto-

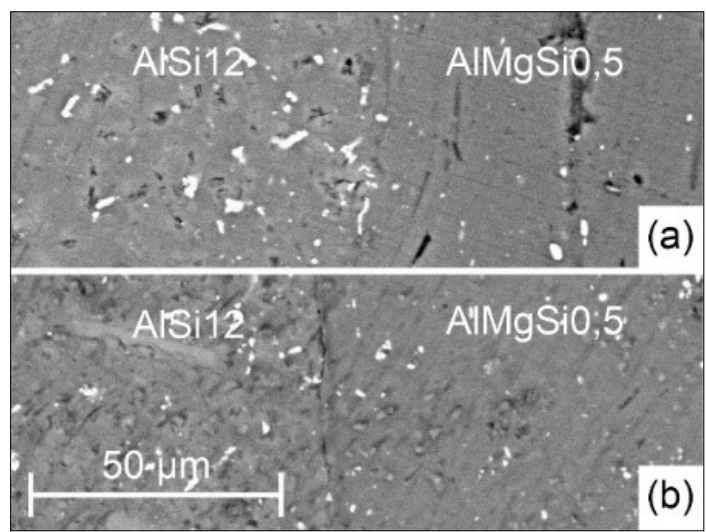

2. ábra. (a) SEM-felvétel a hőkezelés elött (b) és a hökezelést követően in-situ fémhabról zásig együtt haladnak, majd ott kettéválnak. Megfigyelhető továbbá, hogy a hőkezelés nem volt hatással a szintaktikus fémhabok tulajdonságaira, ahogyan az várható volt.

Az is látható, hogy az in-situ fémhabalapú kompozitok tulajdonságait nem befolyásolta jelentősen a hőkezelési eljárás, kivéve egy próbatest tulajdonságait, ahol a kezdeti szakaszban a nyomóerő jelentősen meghaladta a nem hőkezelt in-situ fémhabalapú kompozitokhoz tartozó értékeket, görbéjének jellege pedig hasonlít az ex-situ hőkezelt kompozitokéra. Ennek egy lehetséges oka, hogy a többi hőkezelt próbatest hütése nem volt megfelelően gyors, ami további vizsgálatokat igényel a későbbiekben.

Míg az ex-situ fémhabalapú kompozitok mechanikai tulajdonságai (2. táblázat) javultak a hőkezelés hatására, addig ugyanez nem mondható el az in-situ kompozitokról, azonban a nem hőkezelt in-situ kompozitok nyomófeszültségének szórása igen nagy.

2. táblázat. A zömítővizsgálat eredményei próbatesttípusonként

\begin{tabular}{|l|c|c|}
\hline & $\begin{array}{c}\text { Nyomófeszültség } \\
\boldsymbol{\sigma}_{\mathbf{c}}(\mathbf{M P a})\end{array}$ & $\begin{array}{c}\text { Elnyelt energia } \\
\mathbf{W 5 0 \%} \mathbf{( J / \mathbf { c m } ^ { 3 } )}\end{array}$ \\
\hline Fémhab (O) & $24,75 \pm 4,52$ & $8,88 \pm 1,16$ \\
\hline Fémhab (T6) & 12,19 & 7,47 \\
\hline In-situ (O) & $138,17 \pm 42,79$ & $45,33 \pm 8,62$ \\
\hline In-situ (T6) & $133,09 \pm 10,99$ & $46,13 \pm 6,25$ \\
\hline Ex-situ (O) & $127,45 \pm 0,43$ & $49,09 \pm 0,61$ \\
\hline Ex-situ (T6) & $159,47 \pm 1,93$ & $61,77 \pm 0,44$ \\
\hline
\end{tabular}

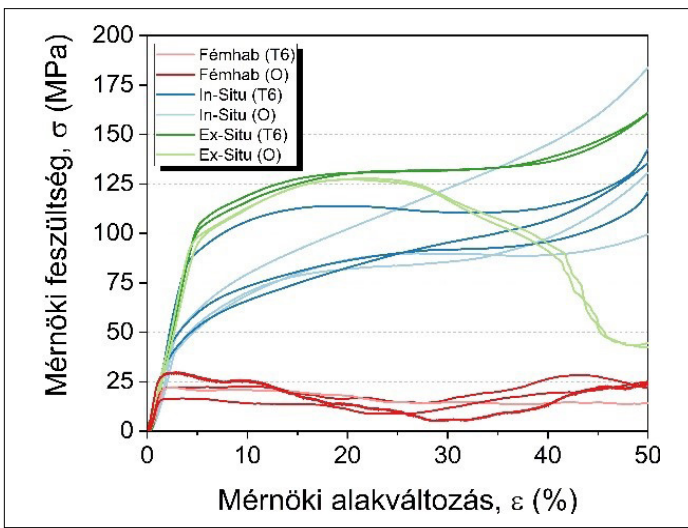

3. ábra. Az egyes próbatestek feszültség - alakváltozás görbéi 


\section{Következtetések}

A kutatásunk során kapott eredményekből az alábbi következtetésekre jutottunk:

- Az alumíniumcsőbe infiltrálással előállított (in-situ), alumíniummátrixú, fémhabalapú kompozit gyártása nemcsak hogy lehetséges, de egyszerü is és rendkívül olcsó.

- A hőkezelés alkalmazása indokolt, mivel:

- Az ex-situ fémhabalapú kompozitok esetén nagyban javítja az anyag tulajdonságait, a cső nem törik darabokra nyomás hatására, és így jelentősen növekszik a kompozit fajlagos energiaelnyelése.

- Megfelelő hőkezelés alkalmazása mellett az in-situ kompozitok megközelítik az ex-situ kompozitok értékeit, ami azért lényeges, mert az in-situ kompozitokat kevesebb lépésben, egyszerűbben és gyorsabban tudjuk legyártani.

- A SEM-felvételeken megfigyelhető, hogy szoros illeszkedés van a cső és a habtömb között, valamint a hőkezelés hatására finomabb kiválások jelentek meg, ami a zömítővizsgálatok eredményei alapján szilárdságnövekedést okoz. Ilyen szoros illeszkedést csőbe sajtolással nem lehet elérni.

\section{Köszönetnyilvánítás}

A publikáció az Innovációs és Technológiai Minisztérium NTP-SZKOLL-20-0067 kódszámú Nemzeti Tehetség Program pályázatának támogatásával valósult meg.

A kutatást támogatta az NKFIH Alap (TKP2020 IES, tsz: BME-IE-NAT; TKP2020 NC, tsz: BME-NCS) az Innovációs és Technológiai Minisztérium vezetése alatt.

Ezt a munkát részben az Országos Tudományos Kutatási Alap támogatta az OTKA FK_21 138505 támogatási szerződés keretében

\section{Szakirodalmi hivatkozások}

[1] Orbulov I. N., Szlancsik A.: On the Mechanical Properties of Aluminum Matrix Syntactic Foams. Advanced Engineering Materials, 170098. (2018). doi.org/10.1002/adem.201700980
[2] Szlancsik A., Katona B., Dombóvári Z., Orbulov I. N.: On the effective Young's modulus of metal matrix syntactic foams. Materials Science and Technology, 33. (2017) 2283-2289. doi.org/10.1080/02670836.2017.1374497

[3] Katona B., Orbulov I. N.: Structural damages in syntactic metal foams caused by monotone or cyclic compression. Periodica Polytechnica, 61/2. (2017) 146-152. doi.org/10.3311/PPme.10346

[4] Yang X., An T., Wu Z., Zou T., Song H., Sha J., He C., Zhao N.: The effect of outer tube on quasi-static compression behavior of aluminum foam-filled tubes. Composite Structures, 245:112357. (2020) doi.org/10.1016/j.compstruct.2020.112357

[5] Linul E., Movahedi N., Marsavina L.: The temperature effect on the axial quasi-static compressive behavior of ex-situ aluminum foam-filled tubes. Composite Structures, 180. (2017) 709-722. doi.org/10.1016/j.compstruct.2017.08.034

[6] Rajak D. K., Mahajan N. N., Linul E.: Crashworthiness performance and microstructural characteristics of foam-filled thin-walled tubes under diverse strain rate. Journal of Alloys and Compounds, 775. (2019) 675-689. doi.org/10.1016/j.jallcom.2018.10.160

[7] Zhang B., Wang L., Zhang J., Jiang Y., Wang W., Wu G.: Deformation and energy absorption properties of cenosphere/aluminum syntactic foamfilled circular tubes under lateral quasi-static compression. International Journal of Mechanical Sciences, 192:106126. (2021). doi.org/10.1016/j.ijmecsci.2020.106126

[8] Garai F., Béres G., Weltsch Z.: Development of tubes filled with aluminium foams for lightweight vehicle manufacturing. Materials Science \& Engineering A, 790:139743. (2020) doi.org/10.1016/j.msea.2020.139743

[9] Movahedi N., Murch G. E., Belova I. V., Fiedler T.: Manufacturing and compressive properties of tube-filled metal syntactic foams. Journal of Alloys and Compounds, 822:153465. (2020). doi.org/10.1016/j.jallcom.2019.153465

[10] Duarte I., Vesenjak M., Krstulović-Opara L., Ren Z.: Static and dynamic axial crush performance of in-situ foam-filled tubes. Composite Structures, 124. (2015) 128-139.

doi.org/10.1016/j.compstruct.2015.01.014 